\title{
THE POOR AND JUSTICE: IMPLEMENTATION OF LEGAL AID FOR THE POOR IN INDONESIA (PROBLEMS AND SOLUTIONS)
}

\author{
Judith Prima Hapsari \\ Faculty of Law, Universitas Negeri Semarang, Indonesia \\ *Email: judith@students.unnes.ac.id
}

\begin{abstract}
One manifestation of justice or equality before the law is the existence of legal assistance for every citizen involved in legal problems, without exception the poor. The legal problems that ensnare many poor people or groups are currently increasing complex. Legal aid is a human right of all people, which is not given by the state and is not a mercy from the state, but is also the responsibility of the state in realizing equality before the law, access to justice, and fair trial. Therefore, the government made and ratified a regulation that regulates legal aid, namely Law Number 16 of 2011 concerning Legal Aid. This research is intended to analyze the implementation of legal aid for the poor communities in the context of access to justice in Indonesia.
\end{abstract}

Keywords: Legal Aid; Advocate; Justice; Poor Community

The Indonesian Journal of International Clinical Legal Education DOI: https://doi.org/10.15294/ijicle.v3i4.48274

Submitted: Dec 12, 2020 Revised: March 13, 2021 Accepted: August 10, 2021 Available online at https://journal.unnes.ac.id/sju/index.php/iccle (C) 2021 Authors. This work is licensed under a Creative Commons AttributionShareAlike 4.0 International License (CC BY-SA 4.0). All writings published in this journal are personal views of the authors and do not represent the views of this journal and the author's affiliated institutions. 
Judith Prima Hapsari

\section{INTRODUCTION}

Indonesia is a legal state that has the obligation to provide protection and recognition of human rights in every individual or citizen, in accordance with Article 1 paragraph (2) of the 1945 Constitution. This is in line with the principle or principle of equality before the law, namely everyone / Citizens have the same position before the law, besides that it is also clarified in Article 27 paragraph (1) of the 1945 Constitution, namely, every citizen has the same position in law and government with no exceptions. One manifestation of justice or equality before the law is the existence of legal assistance for every citizen involved in legal problems, without exception the poor.

The legal problems that ensnare many poor people or groups are currently increasingly complex, thus requiring the Government to immediately pay attention and regulate them in a planned, systematic, sustainable manner and manage them professionally. ${ }^{1}$ Poverty is a complex problem. As we all know, poverty is not only an economic problem, but also a problem in other fields related to humanity. One of the problems faced by the poor is access to justice for those who have problems with the law, where it can be seen that access to justice for the poor is still very minimal. According to Soerjono Soekanto, legal aid basically means that legal assistance is given to experts for people who need to realize their rights and receive reasonable legal protection. ${ }^{2}$

Law enforcement in a broad sense includes the implementation and application of law in both judicial and arbitration procedures. In addition, law enforcement includes all activities that aim to make the law a normative set of rules so that it can regulate and bind all legal subjects in all aspects of state and community life so that they can be obeyed and carried out properly. Enforcement of the law can take a number of activities involving prosecution for any violations or irregularities in the regulations, especially in the judicial process involving the role of the police, prosecutors, advocates/lawyers and judicial institutions. ${ }^{3}$

In Indonesia, the concept of access to justice is defined as a condition and process whereby the state can guarantee the fulfillment of basic rights based on 1945 and universal principles of human rights and guarantee access for every citizen so that they can understand, know, realize and use their rights. these basic rights through various formal and

1 Jimly Assiddiqie, Indonesian Constitution \& Constitutionalism. Revised Edition. Jakarta: Constitution Press, 2005.

2 Ridwan Widyadharma, Legal Professional in Providing Legal Aid. Semarang: Diponegoro University Publishing Agency, 2010.

3 Jimly Asshiddiqie, The idea of people's sovereignty in the constitution and its implementation in Indonesia. Jakarta: Ichitiar Baru-van Hoeve. 1994. 
informal institutions in order to obtain optimal benefits and improve the quality of their own lives. ${ }^{4}$

Therefore, the government makes regulations regarding legal aid by enacting Law No. 16 of 2011 concerning legal aid. This law is the basis of the state to guarantee citizens, especially the poor, to obtain only justice and equality before the law. Where in this case is in accordance with the concept of legal aid itself. The government must provide advocates to provide effective legal assistance for the poor as referred to in Law No. 12 of 2005 concerning the International Covenant on Civil and Political Rights.

The state makes an important aspect in carrying out legal aid through Law no. 16 of 2011 (Law on Legal Aid) has the right to determine who can provide legal assistance to community groups, one of which is an advocate or lawyer. In addition to lawyers who can provide paralegal legal assistance, lecturers and students of the law faculty. Legal aid providers are also entitled to provide services, counseling, and consultations as well as other program activities related to the implementation of legal aid. The concept of access to justice in Indonesia focuses on two basic objectives of the existence of the legal system, namely the legal system should be accessible to all people from various circles, and the legal system should produce provisions or decisions that are fair to all groups, both individuals and groups.

However, in its application in Indonesia, the problem of legal aid is that people who have a low economy (poor) who need a defender to defend their interests, do not have the economic ability to appoint a defender due to economic limitations. In fact, what we know is that the state guarantees the right of the people to get legal aid, especially for the poor.

\section{REALIZING LEGAL AND JUSTICE ACCESS TO LEGAL AID}

Law is seen as one of the important aspects in society which aims to realize the formation of a comfortable and just society. Law is a rule to regulate society, therefore regarding The problem of public legal awareness is starting to play a role again in the formation, application and analysis of law. Thus, legal awareness is seen as a mediator between the law and other forms of human behavior in society.

Theoretically, if it is related to Prof. Satjipto Rahardjo's theory regarding law as a social engineering tool; Law as social engineering is a law that is not only used to strengthen the patterns of habits and behavior that exist in society, but also leads to the goal to be addressed,

4 Bappenas, National Strategy for Access to Justice. Jakarta. 2009. 
eradicating habits that are considered no longer needed and creating new patterns of life. ${ }^{5}$

Access to justice in the Indonesian context refers to the circumstances and processes in which the state guarantees the fulfillment of basic rights based on the 1945 Constitution and universal principles of human rights, and guarantees access for every citizen (claim holder) to have the ability to know, understand, realize and use these basic rights through formal and informal institutions, supported by the existence of a public complaint mechanism that is easily accessible to the public and responsive, in order to obtain optimal benefits to improve the quality of their own lives. ${ }^{6}$

One of the government's efforts to achieve access to law and justice is by issuing an affirmative action policy. Affirmative action is the method chosen by the state as a response to discriminatory social conditions, inequality and marginalization in all areas of life due to patriarchal structures at the public and private levels. ${ }^{7}$ One of the most important means to implement Affirmative Action is the law and guarantees for its implementation there must be a constitution and laws. ${ }^{8}$

Advocates, based on Law No. 18 of 2003 have an obligation to provide legal assistance to the poor because of their position as a noble profession. Ideally, it can be explained that legal aid is the social responsibility of the advocates themselves. Therefore, advocates are required to be able to give their time and skills to poor people who need free legal aid. The provision of legal aid by advocates is not seen as merely an obligation but is also seen as part of social contributions and responsibilities. Legal aid is a human right of all people, which is not given by the state and is not a mercy from the state, but is also the responsibility of the state in realizing equality before the law, access to justice, and fair trial.

The legal system in Indonesia and the 1945 Constitution guarantee equality before the law and the right to be accompanied by an advocate. As previously mentioned, legal aid for the poor is closely related to equality before the law and justice. There are two terms related to legal aid, namely legal aid and legal assistance. Legal aid is usually used to provide services in the field of law to someone involved in a case for free, especially for those who can't afford it. Meanwhile, legal assistance is used to show the meaning of legal aid in a broad sense, because in addition to legal assistance for those who cannot afford it,

5 Satjipto Rahardjo, "Legal Science”, Bandung: Alumni, 1986, pp. 110-111.

6 Supra, Framework for Strengthening Access to Law and Justice in Indonesia, Justice for the Poor Project The World Back : Jakarta. 2005

7 Hendri Yasuti. "The Nature of Affirmative Action in Indonesian Law (Empowerment of the Marginalized)" Jurnal Menara Vol. 12 No. January 1 - June 2013

8 Masnur Marzuki, "Affirmative Action and the Paradox of Democracy" Journal of the Constitution, PSHK-FH UII, Vol. II, No. 1, June 2009 
legal assistance is also provided by lawyers who use or receive payments of a sum of money from clients. ${ }^{9}$

Access to law and justice bridges the reform of legal institutions with public access to these institutions by increasing awareness and trust in law enforcement agencies. While the concept of legal aid itself has 4 concepts in its application, namely, the concept of traditional legal aid where in this case the legal services provided to the poor individually, the nature of passive legal aid and the very formal-legal approach. Furthermore, the concept of constitutional legal aid, where legal assistance for the poor is carried out within the framework of broader efforts and objectives such as making the rights of the poor as legal subjects aware, upholding and developing the value of human rights as the main joint for the establishment of the rule of law. ${ }^{10}$ Then, the concept of structural legal aid, which is an activity that aims to create conditions for realizing laws that can change an unequal structure towards a more just structural one, where legal regulations and their implementation can guarantee equality of position both in the legal and political fields. The concept of structural legal aid is closely related to structural poverty. ${ }^{11}$ Lastly, responsive legal assistance ${ }^{12}$ given to the poor free of charge and covers all areas of law and human rights and without distinguishing between individual and collective defense cases. ${ }^{13}$

The concept of legal aid that can help realize access to law and justice for the poor is the concept of responsive and structural legal aid. If the concept of providing legal aid is combined with the concept of access to law and justice, it is not impossible for the poor to access the law and get justice.

\section{METHODS \& PROCEDURES FOR APPLYING FOR LEGAL AID}

According to Law no. 16 of 2011 (Law on Legal Aid), legal aid is assistance provided free of charge by legal aid providers to legal aid recipients to deal with legal problems that befall them.

9 Sukinta, The Role of Legal Aid Institutions for the Community in Obtaining Justice. Semarang: Faculty of Law, Diponegoro University, 1997.

10 YLBHI, Guide to Legal Aid in Indonesia, Yayasan Obor Indonesia: Jakarta, 2014

11 Suradji, Ethics and Enforcement of the Code of Ethics for the Legal Profession (Advocate). Jakarta: National Legal Development Agency Ministry of Law and Human Rights RI, 2008.

12 Frans Hendra Winata, Probono Publico, Constitutional Right of the Poor to Obtain Legal Aid, Jakarta: PT. Gramedia Pustaka Utama, 2009 p. xii.

13 Suyogi Imam Fauzi and Inge Puspita Ningtyas, "Optimizing the Provision of Legal Aid for the Realization of Access to Law and Justice for the Poor" Journal of the Constitution Vol. 15 No. March 1, 2018 p. 59. 


\section{Judith Prima Hapsari}

According to the provisions of Article 5 of the Law on Legal Aid, people who are entitled to legal aid are recipients of legal aid as referred to in Article 4 paragraph (1), including poor people or groups who are unable to properly and independently carry out their basic rights. The basic rights as referred to in paragraph (1) include the right to food, clothing, health services, education services, employment, and business and/or housing. In the legal aid law, the recipient of legal aid is not clearly defined. However, in principle, it must still refer to the provisions of Article 5 of the Legal Aid Act. Therefore, in general, the objects of legal assistance are people who have problems with civil, criminal, and state administrative law. including litigation and non-litigation as stipulated in Article 4 of the Legal Aid Act. Furthermore, people whose constitutional rights are violated by law enforcement. Furthermore, people who do not get access to justice and people who are persecuted because of the legal case they are facing. These four criteria are not an absolute requirement to get free legal aid, because the four criteria must still refer to Article 5 paragraph (1) of the Legal Aid Act. So legal aid is the right of the poor that can be obtained without paying (pro bono publico) as an elaboration of equal rights before the law. ${ }^{14}$

The Legal Aid Provision Mechanism Mandated by Law Number 16 of 2011 concerning Legal Aid, that the requirements for the Provision of Legal Aid To obtain Legal Aid, Legal Aid Applicants must meet the requirements as stated in Article 14 of the Legal Aid Law, namely:

1. Submit a written application containing at least the identity of the Legal Aid Applicant and a brief description of the subject matter for which Legal Aid is requested;

2. Submit documents relating to the case; and

3. Attach a certificate of poverty from the Lurah, Village Head, or an official at the same level at the place of residence of the Legal Aid Applicant.

If the Legal Aid Applicant is unable to prepare a written application, the application can be submitted orally. Furthermore, the Provision of Legal Aid is carried out by the Legal Aid Provider, who must meet the following requirements:

1. Incorporated;

2. Accredited;

3. Have a permanent office or secretariat;

4. Have an administrator; and

5. Have a Legal Aid program

Procedures for Providing Legal Aid Legal Aid Applicant submits a written application for Legal Aid to the Legal Aid Provider at least containing:

14 Iwan Wahyu Pujiarto, "The implementation of legal aid providers is linked to Law no. 16 of 2011 concerning Legal Aid," USU Law Journal 2, No. 3, 2015. 
1. The identity of the Applicant for Legal Aid is proven by an identity card and/or other documents issued by the competent authority. In the event that the Legal Aid Applicant does not have an identity, the Legal Aid Provider assists the Legal Aid Applicant in obtaining a temporary address certificate and/or other documents from the competent authority according to the domicile of the Legal Aid Provider.

2. The application for Legal Aid as referred to above must attach:

a. Certificate of poverty from the Lurah, Village Head, or an official at the same level at the place of residence of the Legal Aid Applicant. In the event that the Legal Aid Applicant does not have a poverty certificate, the Legal Aid Applicant may attach a Community Health Insurance Card, Cash Direct Assistance, Poor Rice Card, or other documents as a substitute for a poverty certificate (as stated in Article 14 paragraph (1) letter c).

b. Documents relating to the case. In the event that the Legal Aid Applicant does not have the requirements as referred to above, the Legal Aid Provider assists the Legal Aid Applicant in obtaining these requirements. The authorized agency according to the domicile of the Legal Aid Provider is required to issue a temporary address certificate and/or other documents for the purposes of receiving Legal Aid. The Lurah, Village Head, or officials at the same level as the domicile of the Legal Aid Provider are required to issue a poverty certificate and/or other documents in lieu of a poor certificate for the purpose of receiving Legal Aid.

The Legal Aid Provider is obliged to examine and examine all the requirements completely as referred to in Article 6 within 1 (one) working day after receiving the application for Legal Aid. Furthermore, if the application for legal aid has completed the requirements, the Legal Aid Provider is required to submit a written rejection or willingness to the application within a maximum period of 3 (three) working days from the date the application is declared complete.

If the application is complete and the legal aid provider has agreed and is able to provide his assistance, the legal aid provider must provide his assistance based on a special power of attorney from the legal aid recipient. if the application is rejected, the legal aid provider must provide valid reasons in writing within 3 (three) working days after the application is declared complete. Provision of Legal Aid by Legal Aid Providers to Legal Aid Recipients is given until the legal problem is resolved and/or the case has permanent legal force, as long as the Legal Aid Recipient does not revoke the special power of attorney.

In Law Number 18 of 2003, it is obligatory for an advocate or legal adviser to provide legal assistance to underprivileged communities 


\section{Judith Prima Hapsari}

free of charge based on the conditions stipulated in the law. This means that an advocate is a person whose profession is to provide legal services, both inside and outside the court, who meet the requirements based on the provisions of the law. That means that the person who is allowed to provide legal assistance is an advocate. So that an advocate based on the mandate of the law has an obligation to provide legal assistance to everyone who needs it.

As stated in Article 22 of the Law on Advocates, which states that:

a. Advocates are obliged to provide free legal aid to justice seekers who cannot afford it.

b. Provisions regarding the requirements and procedures for providing free legal aid as referred to in paragraph (1) shall be further regulated by a Government Regulation.

However, in reality there are still many advocates who do not want to provide free legal aid because the regulations regarding the provision of free legal aid are not binding on every advocate. The obligation to provide legal assistance should have binding consequences for the advocate. So if an advocate is not willing to carry out these obligations, then they must have consequences. Despite the fact that so far, this code of ethics has not placed much emphasis on the obligation to provide legal aid by every advocate, so that it becomes a gap or opportunity for advocates to avoid providing legal aid. Considering that legal aid may only be provided by an advocate, it is appropriate that every advocate must carry it out as well as possible.

\section{THE PROBLEM OF PROVIDING LEGAL AID TO THE POOR}

In addition, on the other hand, there are several problems in the implementation of providing legal aid in reality so that it cannot realize the existence of access to law and justice for the poor. Problems that hinder the application of legal aid for the poor are the lack of legal awareness of the poor, access to justice which is only a formality, the normative legal framework that does not work in providing legal aid, and the procedure for obtaining legal aid is complicated.

First, the lack of legal awareness of the poor. Ignorance of the law will result in someone breaking the law or someone being fooled by an individual to take advantage, and what is more surprising is that the person is usually from law enforcement or the government. ${ }^{15}$ According to John Rawls "all legal systems will fail if they are not encouraged by a

15 Muhadi Zainuddin, "The Role of Socializing the Law on Advocates in Empowering Community Legal Awareness". Al-Mawarid Journal No. 12, Faculty of Religion UII : Yogyakarta. 2004 p. 93 
genuine personal moral attitude (justice as farness) in society." ${ }^{16}$. It can be seen that based on this opinion, when compared to the application of legal aid for the poor, the poor in reality still lack legal awareness, and legal knowledge of the importance of legal aid, as well as understanding the law itself, then the provision of legal aid does not function optimally.

It can be seen that in the application of providing legal aid for the poor, it is not only seen as meeting the needs of the community who need assistance in the legal process but more than that. That is, to make the public know and understand and understand the law so that they can provide criticism on existing legal products and those that are not in accordance with the community because on the other hand, legal aid can also provide education to the community (civic education). ${ }^{17}$

This thinking can ideally solve a problem, but it is not appropriate in implementation or in reality. Some advocates and legal aid institutions still tend to view the provision of legal aid as passive. The perspective of providing passive legal aid can become a parasite that can reduce the optimization of legal aid provision. Perspectives here can be illustrated such as, the provision of legal assistance provided by advocates or Legal Aid Institutions on the appointment of law enforcement officers, namely the police or courts as legal advisors because of the provision of funds from the court and cases whose penalties are above 15 years in prison as recommended by the Criminal Procedure Code. ${ }^{18}$

Another regulation that enacts the law is PERMA No. 1 of 2014 concerning Guidelines for Providing Legal Services for Poor People in Courts. In this case, the court provides a service to provide free legal aid by establishing a Legal Aid Post (Posbakum) within the Court. ${ }^{19}$ Access to legal aid is carried out by appointing an Advocate or Legal Aid Institute funded by the court with institutional cooperation (Article 26 Perma No. 1 of 2014) while Posbakum itself aims to provide legal consulting services, making required legal documents and information about advocates or institutions. Legal Aid who received legal aid (Article 25 Perma No. 1 of 2014). ${ }^{20}$

16 Theo Huijbers, Philosophy of Law in Historical Crosses, Yogyakarta: Kanisius. 2013 pp. 193-202

17 Binziad Kadafi, Indonesian Advocate Seeking Legitimacy: A Study on the Responsibilities of the Legal Profession in Indonesia. Jakarta: Center for Legal Studies and Legal Policy. 2001 p. 182.

18 Iwan Wahyu Pujiarto, et al. "Implementation of Legal Aid Providers is Associated with Law no. 16 of 2011 concerning Legal Aid”, USU Law Journal, Vol. 3 No. 2 August 2015 edition, USU Faculty of Law: North Sumatra, page 90.

19 Andry Rahman Arif, "Implementation of Providing Legal Aid to Incapacitated Defendants in Criminal Cases in Bandar Lampung City", Journal of Fiat Justitia, Vol. 9 No. 1 January-March 2015 issue, p. 106

20 Isnandar Syahputra Nasution, "The Urgency of the Court's Role in Providing Legal Aid Services to the Poor in accordance with Law No. 16 of 2011 concerning Legal Aid", Journal of Law and Justice, Vol. 4 No. 1 March 2015 issue, p. 185. 
With the existence of the principle of legal aid, in fact, there are new problems, namely limitations in budget procurement in fulfilling this legal aid. This will raise the next problem. Based on the perspective that the provision of legal aid is passive and the limited access provided by the court will reduce the optimization of the provision of legal aid for the poor. This makes the urgency of the sensitivity of advocates or Legal Aid Institutes to view the provision of legal aid actively and not rely too much on the access provided by the court.

The next problem is regarding access to justice as if it were a formality. From the sentence "the blade of the law is sharper down than up" which means that we can know that justice in law is only owned by the rich and will get special treatment, while the poor will not. ${ }^{21}$ The application of this law is carried out by the judge as one of the actors of law enforcement itself due to an error in persona as a controller of the court process and judicial practice in Indonesia. ${ }^{22}$

Often in practice in the community, especially the poor people become victims in court, although there is access to appeal, cassation and review to avoid mistakes in the judiciary, this access is not yet possible for the poor to use because it will incur a lot of costs that they cannot afford to pay. Based on this, the existence of the Law on Legal Aid is not a guarantee for the poor to get access to appeal, cassation or judicial review. This is because the application of legal aid in the community is only a formality by some advocates and legal aid institutions. ${ }^{23}$ From the point of view of an advocate or Legal Aid Institute, this is done at the request of the client (the poor), but from a different point of view the request (no appeal, cassation, reconsideration) is based on submission and does not have the cost to access it. .

A matter that becomes a dilemma, where the Law on Legal Aid requires to provide legal aid for the poor free of charge sourced from the APBN and APBD and Perma No. 1 of 2014 which is sourced from the local court budget, normatively legal aid is purely free, without any other costs, but this is inconsistent in practice in society, where the poor are still charged with fees such as photocopying fees, summoning witnesses and experts, as well as transportation costs are the responsibility of the poor in receiving legal aid. ${ }^{24} \mathrm{~A}$ fee is levied on the basis of supporting and

21 Alfan Biroli, "Problematics of Law Enforcement in Indonesia (Study with the Perspective of Sociology of Law)", Dimensi Journal, Vol. 8. No.2 of 2015, p. 24

22 Rahmat Efendy Al Amin Siregar, "Study of the Heretical Court (Rechterlijke Dwaling) and its Relationship with the Fading of Public Trust in the Law", Journal of FITRAH, Vol. 8 No. 1 January-July 2014 edition, p. 22.

23 Dony Michael, "The Role of Local Governments in Fulfilling the Right to Justice (Study on Access to Legal Aid for the Poor in East Java Province), Journal of Human Rights, Vol. 3 No. 2 of 2012, BPHN : Jakarta, page 50.

24 Suyogi Imam Fauzi and Inge Puspita Ningtyas, "Optimizing the Provision of Legal Aid for the Realization of Access to Law and Justice for the Poor" Journal of the Constitution Vol. 15 No. March 1, 2018 p. 64 
paying the work costs of an advocate or Legal Aid Institute. In fact, collecting fees for legal aid is a prohibition with a maximum imprisonment of 1 year and a fine of fifty million rupiah (Article 20 in conjunction with Article 21 of the Law on Legal Aid). This becomes a dilemma in the application of legal aid for the poor. ${ }^{25}$

Then there is the issue of the normative legal framework for the application of legal aid that does not work. In the opinion of Satjipto Rahardjo "Laws that were created and have never been implemented have essentially ceased to be laws". ${ }^{26}$ The normative legal framework regarding the provision of legal aid at the level of practice in the community, especially for the constituents of the regulation, namely the poor are still not carried out optimally by advocates as one of the legal aid providers. There are three things the behavior of advocates in dealing with the problem of assistance for the poor, namely avoiding for various reasons, accepting the case on the condition that the case must attract the mass media so that it raises the prestige of the advocate, and finally fully accepting the provision of legal aid.

Some advocates are more inclined to defend clients who have a high economy than the poor, this can reduce the advocate profession as a noble profession into a commercial profession. Based on the results of the study, there were almost some advocates who were reluctant to provide legal assistance/defense on a pro bono publico basis to the poor by rejecting cases that were not objective. The objective thing in question is the rejection of cases that are not legal problems, meaning that the problem is not included in the category of legal problems that do not cause legal consequences. Advocates' non-objective refusal usually rejects sexual harassment cases, fights the government, or even rejects the case because the case is not a big case that will not be published by the mass media. The non-objective rejection of cases experienced by the poor by advocates is a deviation from the normative legal framework of providing legal aid, because normatively legal aid is given without knowing what legal problems will be handled and who will be defended, but how the poor get the right to access. to law and justice when the poor are in trouble with the law. When the normative framework for providing legal aid is not carried out by advocates, the law regarding legal aid does not become law, in other words, regulations regarding legal aid are just a myth created by the state. because normatively legal aid is given without knowing what legal problems will be handled and who will be defended, but how the poor get the right to access to law and justice when the poor have problems with the law. When the normative framework for

25 Agus Raharjo, Angkasa, and Rahadi Wasi Bintoro, "Access to Justice for the Poor (Dilemma of Providing Legal Aid by Advocates)", Journal of the Legal Pulpit, Vol. 27 No. 3 October 2015 edition, Faculty of Law UGM: Yogyakarta, pp. 442-443.

26 Satjipto Rahardjo, "Law and Social Change", Genta Publishing: Yogyakarta, 2009, p. 69 
providing legal aid is not carried out by advocates, the law regarding legal aid does not become law, in other words, regulations regarding legal aid are just a myth created by the state. because normatively legal aid is given without knowing what legal problems will be handled and who will be defended, but how the poor get the right to access to law and justice when the poor have problems with the law. When the normative framework for providing legal aid is not carried out by advocates, the law regarding legal aid does not become law, in other words, regulations regarding legal aid are just a myth created by the state.

And the last is the problem of discrimination and the complicated procedures for obtaining legal aid and funding. Funding in legal aid is a form of responsibility and enthusiasm given to the state to advocates or Legal Aid Institutions because it is obligatory to provide legal aid to the poor. The Law on Legal Aid provides funding for lawyers or Legal Aid Agencies with a variety of complicated requirements and procedures. The conditions given are more likely to be fulfilled by the Legal Aid Institute alone, and even then there must be a selection process commonly referred to as accreditation as legitimacy to absorb the legal aid funding, this has the tendency of discrimination. It is known that the process of accreditation and absorption of funds is complicated and tends to be discriminatory which can result in the absorption of legal aid funds nationally being ineffective. This tends to cause many advocates or Legal Aid Institutions to collect other fees in providing legal aid.

Optimizing the application of providing legal aid for the poor, it is necessary to know beforehand that the implementation of providing legal aid in practice in the community is not optimal because it still has various kinds of systematic problems that have an impact on the lack of access to law and justice for the poor. Therefore we need an idea that can solve problems in the application of providing legal aid for the poor, so that the realization of access to law and justice is not just a formality made by the state. Refers to the definition and strategy for the realization of access to law and justice.

There are efforts that can optimize the application of legal aid for the poor, namely:

\section{Active, Structural and Responsive Legal Aid}

This is necessary due to the limitations of clients (poor people) who still do not have the knowledge, understanding and awareness of the laws and budgets provided by the courts and the state. Furthermore, what is meant by being active and responsive is that advocates should know more about the needs of clients when they have legal problems without having to wait for requests from clients, law enforcement officers, or courts. While structural in this case, namely advocates in providing legal assistance not only to solve problems in court (legal advisors), but advocates or Legal Aid Institutions make their clients understand the law more so that a structural legal 
awareness is created, this places Advocates are not only legal advisors but also legal mentors.

2. All access to justice is reached

When advocates or legal aid institutions have agreed that the orientation of legal aid must be active, responsive and structural, it will make all access to justice accessible (such as courts of first instance, appeal, cassation, and judicial review), so that clients can use their rights in full to access law and justice.

3. There is supervision in the implementation of the provision of Legal Aid

Supervision is an important thing in the application of legal aid in Indonesia to minimize the existence of limits that are exceeded or there is abuse in its application. A supervisory system is needed to oversee several components of the implementation of legal aid. Supervision in the application of legal aid plays an important role in maintaining the balance of legal aid relations according to their designation. Loose supervision can open a gap to misappropriate state money (corruption) or even sacrifice hopes for the realization of access to law and justice for the poor.

\section{CONCLUSION}

The legal system in Indonesia and the 1945 Constitution guarantee equality before the law and the right to be accompanied by an advocate. Legal aid for the poor is closely related to equality before the law and justice. There are two terms related to legal aid, namely legal aid and legal assistance. Legal aid can help realize access to law and justice for the poor. It can be seen that in the application of providing legal aid for the poor, it is not only seen as meeting the needs of the community who need assistance in the legal process but more than that. However, the application of providing legal aid in practice in the community is not optimal because it still has various kinds of problems that are systematic so that it has an impact on the lack of realization of access to law and justice for the poor.

\section{REFERENCES}

Angga, A., \& Arifin, R. (2019). Penerapan Bantuan Hukum Bagi Masyarakat Kurang Mampu di Indonesia. DIVERSI: Jurnal Hukum, 4(2), 218-236.

Arif, A. R. (2015). Pelaksanaan Pemberian Bantuan Hukum Terhadap Terdakwa Yang Tidak Mampu Dalam Perkara Pidana Di Kota 


\section{Judith Prima Hapsari}

Bandar Lampung. Fiat Justisia: Jurnal Ilmu Hukum, 9(1), 103113. https://doi.org/10.25041/fiatjustisia.v9no1.591

Asshiddiqie, J. (1994). Gagasan kedaulatan Rakyat dalam Konstitusi dan Pelaksanaanya di Indonesia. Jakarta: Ichitiar Baru-van Hoeve.

Assiddiqie, J. (2005). Konstitusi \& Konstitusionalisme Indonesia. Edisi Revisi. Jakarta: Konstitusi Press.

Biroli, A. (2015). Problematika Penegakan Hukum Di Indonesia (Kajian Dengan Perspektif Sosiologi Hukum). DIMENSI-Journal of Sociology, 8(2).

Fauzi, S. I., \& Ningtyas, I. P. (2018). Optimalisasi Pemberian Bantuan Hukum Demi Terwujudnya Access to Law and Justice bagi Rakyat Miskin. Jurnal Konstitusi, 15(1), 50-72.

Huijbers, T. (2013). Filsafat Hukum dalam Linstas Sejarah. Yogyakarta: Kanisius.

Marzuki, M. (2009). Affirmative Action dan Paradoks Demokrasi. Jurnal Konstitusi, 2(1), 8-23.

Michael, D. (2012). Peran Pemerintah Daerah Dalam Pemenuhan Hak Atas Keadilan (Studi Tentang Akses Bantuan Hukum Bagi Masyarakat Miskin di Provinsi Jawa Timur). Jurnal Hak Asasi Manusia, 3(2), 24-54.

Nasution, I. S. (2015). Urgensi Peran Pengadilan dalam Memberikan Pelayanan Bantuan Hukum terhadap Orang Miskin Sesuai Undang-Undang Nomor 16 Tahun 2011 tentang Bantuan Hukum. Jurnal Hukum dan Peradilan, 4(1), 171-188.

Pujiarto, I. W., Kalo, S., \& Ikhsan, E. (2016). Pelaksanaan Pemberi Bantuan Hukum Dikaitkan dengan Undang-undang No. 16 Tahun 2011 Tentang Bantuan Hukum. Arena Hukum, 8(3), 318-341.

Rahardjo, S. (1986). Ilmu Hukum. Bandung: Alumni.

Rahardjo, S. (2009). Hukum dan Perubahan Sosial. Yogyakarta: Genta Publishing.

Raharjo, A., Angkasa, A., \& Bintoro, R. W. (2015). Akses Keadilan Bagi Rakyat Miskin (Dilema dalam Pemberian Bantuan Hukum oleh Advokat). Mimbar Hukum-Fakultas Hukum Universitas Gadjah Mada, 27(3), 432-444.

Republic of Indonesia. (2003). Undang-Undang Nomor 18 Tahun 2003 tentang Advoat atau Penasehat Hukum.

Republic of Indonesia. (2005). Undang-Undang Nomor 12 Tahun 2005 tentang Konvenan Internasional Hak Sipil dan Politik.

Republic of Indonesia. (2011). Undang-Undang Nomor 16 Tahun 2011 tentang Bantuan Hukum.

Sayuti, H. (2013). Hakikat Affirmative Action dalam Hukum Indonesia (Ikhtiar Pemberdayaan yang Terpinggirkan). Menara Riau, 12(1), 41-47. 
Siregar, R. E. A. A. (2014). Studi Tentang Peradilan Sesat (rechterlijke dwaling) dan hubungannya dengan memudarnya kepercayaan masyarakat terhadap hukum. Jurnal FITRAH, 8(1), 17-30.

Sukinta, S. (1997). Peranan Lembaga Bantuan Hukum Bagi Masyarakat dalam Memperoleh Keadilan. Semarang: Fakultas Hukum Universitas Diponegoro.

Supra, S. (2005). Kerangka Kerja untuk Penguatan Akses Hukum dan Keadilan di Indonesia. Jakarta: Justice for the Poor Project The World Back.

Suradji, S. (2008). Etika dan Penegakan Kode Etik Profesi Hukum (Advokat). Jakarta: Badan Pembinaan Hukum Nasional Departemen Hukum dan HAM RI.

Widyadharma, R. (2010). Profesional Hukum dalam Pemberian Bantuan Hukum. Semarang: Badan Penerbit Universitas Diponegoro.

Winata, F. H. (2009). Probono Publico, Hak Konstitusional Fakir Miskin Untuk Memeperoleh Bantuan Hukum. Jakarta: PT. Gramedia Pustaka Utama

YLBHI. (2014). Panduan Bantuan Hukum di Indonesia. Jakarta: Yayasan Obor Indonesia.

Zainuddin, M. (2004). Peran Sosialisasi UU Advokat dalam Pemberdayaan Kesadaran Hukum Masyarakat. Al-Mawarid Journal of Islamic Law, 12(11), 91-109. 


\section{"At his best, man is the \\ noblest of all animals; separated from law and justice he is the worst."}

\section{Aristotle}

\section{Conflicting Interest Statement}

All authors declared that there is no potential conflict of interest on publishing this article.

\section{Funding}

None

\section{Publishing Ethical and Originality Statement}

All authors declared that this work is original and has never been published in any form and in any media, nor is it under consideration for publication in any journal, and all sources cited in this work refer to the basic standards of scientific citation.

Cite this article as:

Hapsari, J. P. (2021). The Poor and Justice: Implementation of Legal Aid for the Poor in Indonesia (Problems and Solutions). The Indonesian Journal of International Clinical Legal Education, 3(4), 553-568. https://doi.org/10.15294/ijicle.v3i4.48274 